\title{
INFLUENCE OF TRAINING PROMOTION OF SUSTAINABLE PRINCIPLES OF HEAD OF SUPERVISION FIELD OF ACADEMIC AND MENTORING SUPERVISION FOR SUPERVISION ACADEMIC
}

\author{
Akhmad Murbawi \\ Manajemen Pendidikan STIA Bina Banua \\ Banjarmasin, Indonesia \\ ahmad_samawi61@yahoo.com
}

\author{
Agustina Rahmi \\ Manajemen Pendidikan STIA Bina Banua \\ Banjarmasin, Indonesia \\ rahmitina14@gmail.com
}

\begin{abstract}
The purpose of this research is to know the influence caused by training of professional development of principal of academic supervision and supervisor supervising on the management of academic supervision on SD pilot project in East Banjarmasin Subdistrict. The method used is quantitative descriptive approach. Data collection techniques with questionnaires. Researcher use validity and reliability test for instrument, kemudaian data analyzed with descriptive analysis and inferential analysis (determinasi). Both correlations are operated using SPSS with a significance level of 0.05 to determine the relationship of each variable. The results show: 1) there is a significant influence between the training of the principal's sustainable development of the academic supervision on the SD pilot project, 2) there is no significant influence between supervisor mentoring on the management of academic supervision on elementary school pilot project; 3 ) there is significant influence Between continuous professional training of headmaster training and supervisor mentoring on the management of academic supervision on elementary school pilot project.
\end{abstract}

Keywords: training on continuous professional development, supervisor mentoring, management of academic supervision

\section{INTRODUCTION}

One of the dimensions of the principal's competence, in accordance with Permendiknas Number 13 of 2007 on Standards of Principals is the competence of supervision. Supervision that must be done by the principal is academic supervision. Academic supervision is a series of activities to help teachers develop their ability to manage learning processes to achieve learning objectives [8]. Efforts to realize the improvement of academic supervision for each principal, the Center for the Development of Teaching Personnel (Pusbang Tendik), Human Resources Development Board of Education \& Culture and Quality Assurance of Education (Badan PSDMP \& $\mathrm{K}$ and PMP), Ministry of Education and Culture in cooperation with AEPI -SSQ AusAID (Australia's Education Partnership with Indonesia - School Systems and Quality) holds a 1st level (1st level) professional development training (PBK) training for headmasters [1]. The training of the headmaster level 1 is for the beginner's headmaster (his / her working days as principal about four years and below).

This training pattern of head / school level 1 PKB there are three models, namely LPMP model, District model, and K3S model [1], [2]. South Kalimantan uses LPMP model, the training committee is from LPMP with the resource person or facilitator is the Widyaiswara who is trusted for it. The pattern of $\mathrm{PKB}$ training is through three stages, namely the first stage of what is called In Service Learning 1 (In-1), the participants directly face-to-face with the facilitator (LPMP Widyaiswara) to learn together about various important information both material. Such as the management of educators and education personnel in schools [3], management of school facilities and infrastructure, school financial management, and management of academic supervision [6], or activities they undertake to improve their competence. In this activity each principal is focused on one of the four management, for example only about the management of academic supervision [6].

The second stage of the activity is On The Job Learning (OJL), an activity in which each principal applies what they have learned to In-1 with material specificity, for example on academic supervision. This stage every principal is accompanied by school supervisors who have been trained on the PKB [4], [5]. The supervisor is assigned as mentor or assistant to assist the completion of tasks of the principal in implementing its OJL [7]. The third stage is In Service Learning 2 (In-2), ie every headmaster comes to meet with the headmaster / other madrasah, together doing reporting activities from OJL results. $\mathrm{Eg}$ about academic supervision to be presented and discussed with the facilitator's guidance.

This pattern of PKB training activities from In-1, OJL, and ending In-2, in addition to taking a long time, also requires a considerable cost, because it is expected to impact on improving the head of school / madrasah. SDN Kebun Bunga 5, SDN Sungai Bilu 1, and SDN Pekapuran Raya 1 Banjarmasin as the school that became the piloting of PKB training in East Banjarmasin Subdistrict, focusing on the management of academic supervision. Therefore, the researcher is interested to conduct research under the title of influence of training of professional development of school principal of academic supervision and mentoring supervisor on management of academic supervision at SD Pilot Project in East Banjarmasin Subdistrict.

\section{METHODS}

This research uses descriptive method with quantitative technique, that is giving description about the influence of professional development training of keprofesionalan (PKB) principal and supervisor mentoring on supervision of academic supervision at SD pilot project in East Banjarmasin Subdistrict. 
Subjects in this study were principals and teachers in elementary school pilot project PKB school principal in the field of academic supervision of East Banjarmasin District. Instruments in this study is a questionnaire.

To measure each instrument item in this research is by using rating scale (scale of scale) that is likert scale with five scale. Data collection in this research using questionnaire technique. Before the questionnaire was disseminated in the study, the questionnaire was tested first by using validity and reliability test. Data processing validity test and reliability test in this study using computer program SPSS 22. Analytical techniques used in this study are descriptive analysis, inferential analysis, and hypothesis testing ( $\mathrm{t}$ test and $\mathrm{F}$ test) is done with the help of SPSS 22 .

\section{RESULTS AND DISCUSSION}

The results of this study were revealed by means of the scale of his attitude. The attitude scale is determined by the statement then the respondent chooses one alternative of the five options provided are: always $(\mathrm{S})$, often $(\mathrm{Sr})$, occasional $(\mathrm{KK})$, rarely $(\mathrm{J})$, and never (TP). The results of the instruments that have been disclosed by respondents, then disclosed by using SPSS version 22, a mean value on each item, then determine category per item. Then, the average variable is also determined and it reveals the category of the variable in question. In the variable of PKB School Principal training in the field of academic supervision score average 4.47 with good category, so it can be concluded that the training of professional development of the principal of academic supervision is good, because he can understand how to make academic supervision plan, understand how to implement it, Analyze the results of supervision implementation, and understand how to do feedback and follow-up.

In the variable of PKB School Principals training in mentoring supervisor score average score 4.05 with good category, so it can be concluded that supervisor mentoring include competence about academic supervision, how to do mentoring, and how to assess principal about the implementation of academic supervision is good. In academic supervision management variable score of 4.52 score with very good category, it can be concluded that the management of academic supervision includes preparing the academic supervision plan, carry out academic supervision, analyze the results of academic supervision implementation, and do feedback and follow-up is very good.

As for, to know the magnitude of the influence / contribution of the Principal Academic Supervision Development Training on Academic Supervision Management can be done by looking at the value of $\mathrm{R}$ Squere. Furthermore, to know the significance of the Training of Professional Development of School Principal of Academic Supervision Division of Academic Supervision Management at SD pilot project in East Banjarmasin Subdistrict is done by testing t. The step taken is to compare the value of tcount with ttable value at $5 \%$ real level. The value of $\mathrm{R}$ Squere was obtained at 0.978 . This shows that the Training of Professional Development of School Principal of Academic Supervision Affects the Management of Academic Supervision of $97.8 \%$, while the $2.2 \%$ is influenced by other factors. It can be explained also that the variable of Training of Principal Development of Principal Development (X1) which has tcount = 6.634 ttabel $=2.353$ means that the variable of Principal Training of Principal Leadership at 5\% significant level has significant influence to Academic Supervision Management at SD Pilot Project In the District of East Banjarmasin. The first hypothesis of the hypothesis is known, There is an influence of the principal's ongoing professional training on the management of academic supervision at elementary school pilot project in East Banjarmasin subdistrict' can be declared accepted. This means that the increase and decrease in professional development training with the headmaster of the school could have an impact on the management of academic supervision on elementary school pilot project in district East Banjarmasin.

On the influence / contribution of Mentoring Supervisor on Management of Academic Supervision $\mathrm{R}$ Squere value that is equal to 0.751 . This indicates that Mentoring Supervisor has an effect on Management of Academic Supervision equal to $75.1 \%$, while $24.9 \%$ is influenced by other factors. It can be explained also that the Mentoring Supervisor (X2) which has tcount $=1.738$ ttable $=2.353$ means that Mentoring Supervisor variable at 5\% real level has no significant influence on Academic Supervision Management at SD Pilot Project in East Banjarmasin Subdistrict. When viewed from the value of titung independent variables, the supervisor Mentoring variable $(\mathrm{X} 2)$ which has $t$ count $=1.738$ smaller than ttable $=2.353$ can be said that the second hypothesis in this study that states. There is influence from mentoring supervisor on the management of academic supervision on elementary school pilot project In the District of East Banjarmasin can be declared rejected. This means that the increase and decrease in supervisory mentoring training can have an impact on the management of academic supervision on elementary school pilot projects in East Banjarmasin Subdistrict.

On the influence / contribution from Training of Principal Development of Academic Supervision and Mentoring Supervisor of Academic Supervision Management can be done by looking at the value of $\mathrm{R}$ Squere. Furthermore, to know the significance of the Training on Sustainable Development of School Principal of Academic Supervision and Mentoring Supervision of Academic Supervision Management at SD pilot project in East Banjarmasin District is done by testing F. Based on the calculation done by using SPSS version 22.

The value of $\mathrm{R}$ Squere is 1.00 . This shows that the Training of Professional Development of School Principal of Academic Supervision Division gives the Academic Supervision Management a $100 \%$ significance. This can be explained by comparing 
Fcount with Ftable at the real level $\alpha=0.05$, it is known that Fcount $=33.53$ Ftable $=18.51$. This means that the Training on Sustainable Principal Development of the Supervisory School for Academic Supervision and Mentoring of Supervisors has a significant influence on the Management of Academic Supervision at SD Pilot Project in East Banjarmasin Subdistrict, or in other words it can be stated that the third hypothesis states. There is an influence of development training Sustainability of principals in the field of academic supervision and mentoring of school supervisors on the management of academic supervision of elementary school pilot project in East Banjarmasin District is accepted. This means that the improvement and decrease of professional head teacher development training in supervision and supervisor supervisory can have an impact on the management of academic supervision on elementary school pilot project in East Banjarmasin Subdistrict.

\section{Conclusion}

\section{CONCLUSIONS AND RECOMMENDATIONS}

Based on the results of data analysis and discussion of research results, it can be concluded as follows: (1) Continuing Professional Training of Principal Academic Supervision Sector, including: preparing academic supervision plan, supervising academic, menganganaisis results of academic supervision, Advanced is good. Mentoring Supervisors, including: supervisory competence on academic supervision, methods used in mentoring, and passing the assessment of the implementation of academic supervision conducted principals is good. Supervision of Academic Supervision, including: preparing academic supervision plan, conducting academic supervision, analyzing the results of academic supervision, doing feedback and follow up is very good, (2) Training of Principal Development of School Principal have big influence and significant to management of academic supervision At SD pilot project in East Banjarmasin Subdistrict, (3) Mentoring Supervisors have a significant but not significant influence on the management of academic supervision on elementary school pilot project in East Banjarmasin Subdistrict, and (4) Training on Sustainable Development of School Principals and Mentoring Supervisors have a very big and significant influence on the management of academic supervision on elementary school pilot project in East Banjarmasin Subdistrict.

\section{Suggestions}

Based on the result of the research, it is suggested as follows: (1) Human Resources Development Board of Education \& Culture and Guarantor of Quality of Education, Ministry of Education and Culture in order to continue this PKB training because of its influence on the management of academic supervision in school; (2) mentor (pengawas pembina) to be more optimal in the execution of task mentoringnya because there is influence on the management of academic supervision though not significant; and (3) other researchers, in order to continue this research on other main learning materials (BPU), such as management of school sapras, or school financial management, or management of educators \& education personnel.

\section{REFERENCES}

[1] Badan Pengembangan Sumber Daya Manusia Pendidik \& Pendidikan dan Penjaminan Mutu Pendidikan Kemendikbud. 2012. Panduan Pengembangan Keprofesian Berkelanjutan Kepala Sekolah/Madrasah. Jakarta: Badan PSDM \& K dan PMP.

[2] Hasanah, D. S. 2010. Pengaruh Pendidikan Latihan Kepemimpinan Guru dan Iklim Kerja terhadap Kinerja Guru Sekolah Dasar Se Kecamatan Babakancikao Kabupaten Purwakarta. Jurnal Penelitian Pendidikan, 11, 2, 1-11.

[3] Mapparenta. 2010. Pengaruh Tingkat Pendidikan Pelatihan dan Disiplin Kerja Terhadap Produktivitas Kerja Pegawai Sekretariat Daerah Kabupaten Halmahera Timur Provinsi Maluku Utara. Jurnal Teknik Industri, 10, 2, 191-199.

[4] Mursidi. 2009. Pengaruh Pendidikan dan Pelatihan Terhadap Kinerja Karyawan Universitas Muhammadiyah Malang. Jurnal Economic Resource, $11,30,12-19$.

[5] Rohman, M., dan Amri, S. 2012. Manajemen Pendidikan Analisis dan Solusi terhadap Kinerja Manajemen Kelas dan Strategi Pengajaran yang Efektif. Jakarta: Prestasi Pustaka Publisher.

[6] Sahertian, P. A. 2008. Konsep Dasar \& Teknik Supervisi Pendidikan dalam Rangka Pengembangan Sumber Daya Manusia. Jakarta: Rineka Cipta.

[7] Umam, A. F. 2011. Pengaruh Pengalaman Kerja, Motivasi Kerja dan Supervisi Kepala Sekolah Terhadap Kinerja Guru SD Di Kecamatan KIesugihan Kabupaten Cilacap Tahun Pelajaran 2010/2011. Thesis. Yogyakarta: Sarjanawiyata Tamansiswa University.

[8] Wardono, M. N. S. 2012 Pengaruh Pendidikan Pelatihan dan Motivasi terhadap Kinerja Pegawai di Kantor Kecamatan Semen Kabupaten Kediri. Jurnal Penelitian Pendidikan, 1, 2, 12-18.

[9] Yahya, M. 2003. Metodologi Penelitian. Banjarmasin: Program Pascasarjana Sekolah Tinggi Ilmu Administrasi STIA Banjarmasin. 